\title{
Aspartate Transaminase (AST) Activity in Selected Tissues \& Organs of Clarias Gariepinus Exposed To Different Levels of Paraquat
}

\section{Wala Chimela $^{1 *}$, Nwibari Mesua ${ }^{2}$ and Bawa-Allah Abdulraheem ${ }^{1}$}

${ }^{1}$ Deparment of Biological Sciences, Faculty of Science, Nigeria Police Academy, Wudil Kano, Nigeria

${ }^{2}$ Hydrobiology and Fisheries Unit, Department of Animal \& Environmental Biology Faculty of Biological Sciences, College of Natural and Applied Sciences, University of

Port- Harcourt, Nigeria

\begin{abstract}
Analyzing the activities of aspartate transaminase in tissues can help detect tissue damage cause by toxicants such as paraquat. The activities of aspartate transaminase (AST) in some tissues and organs of Clarias gariepinus exposed to various levels of paraquat $(2,4,6$ and $8 \mathrm{ppm})$ were studied for a period of thirty (30) days. The tissues and organs investigated include blood plasma, kidney, liver, gills and muscle. The result showed changes in AST activity in the treatment group as compared to the control group; however the increase was not concentration dependent. AST activity was highest in the liver (445.00 $\pm 0.00 \mathrm{IU} / \mathrm{L}$ SD) and lowest in the gill $(65.00 \pm 27.39 \mathrm{IU} / \mathrm{L}$ SD) in the control group. There was no significant change in AST activity in the liver across the treatment range. AST activity however declined in the muscle with the lowest at 6ppm of paraquat. There was a significant increase in AST activity in the gills at $4 \mathrm{ppm}$ of paraquat, this later declined to almost control levels at higher concentrations. In the kidneys AST activity also significantly peaked at $4 \mathrm{ppm}$ of paraquat. This declined slightly and was maintained at higher treatment concentrations. AST activity peaked in the plasma at $4 \mathrm{ppm}$ of paraquat as well. This dropped slightly and picked up at $8 \mathrm{ppm}$. Analyzing the activities of AST in tissues can help detect tissue damage cause by toxicants such as paraquat. It can consequently be inferred that AST activity can be used as a reliable biomarker for diseased condition in the plasma, gills and kidney but not the liver or muscle of Clarias gariepinus.
\end{abstract}

Keywords: Enzymes; Herbicides; Toxicant

\section{Introduction}

The aquatic ecosystem suffers much as a result of pollutants that enter the aquatic environment. Agricultural practices vis-à-vis the use of herbicides and pesticides that end up in the aquatic environment contribute immensely to the pollution of water bodies which is detrimental to the aquatic ecosystem. Paraquat is one of the herbicides widely used in the control of weeds and it finds its way into the aquatic environment rendering it polluted. Fish is one of the aquatic biota that is adversely affected by this situation in both captured and cultured fisheries. Several tissues and organs of the fish suffer as a result of aquatic pollution. Their enzymes, physiological functions and ability to resist diseases are also affected. Several fishes like Clarias gariepinus (African Catfish) which occupy vital positions in the fish industry of the Niger Delta region of Nigeria in particular as well as the world over [1]. Enzymes play vital roles in the existence and functioning of various organs and tissues of fishes. Aspartate transaminase, (AST) is one enzyme that is of vital importance to fishes. This enzyme is widely distributed in many tissues and organs being abundant in the liver, myocardium, skeletal system, muscles, kidneys and erythrocytes. AST catalyzes the transfer of a-amino group of aspartic acid to a-ketoglutarate which eventually results in the formation of oxaboacetic acid and glutamic acid respectively. Analyzing the activities of AST in tissues can help detect tissue damage cause by toxicants.

\section{Materials and Methods}

5 groups of fishes (20 in each group) were studied in the experiment. The first group was the control group placed in an aquarium containing no paraquat. The second to fifth groups of fishes were placed in aquaria containing 2ppm, 4ppm, $6 \mathrm{ppm}$ and $8 \mathrm{ppm}$ of paraquat respectively. The fishes were fed with $30 \%$ of crude protein at $1 \%$ body weight. After thirty (30) days, $0.5 \mathrm{~g}$ of each of the organs (Kidneys, livers, gills and muscles) was macerated and analyzed for aspartate transaminase (AST) using the Reitman-Frankel (1957) method.
The results obtained were analyzed using one-way analysis of variance (ANOVA) to test if exposure to paraquat produced any significant differences in enzymes activities in various organs tissues at different concentration levels of paraquat. Where differences were found, Duncan's multiple range test (DMRT) was used to compare or separate differences between means.

\section{Results}

The result showed changes in AST activity in the treatment group as compared to the control group. AST activity was highest in the liver $(445.00 \pm 0.00 \mathrm{IU} / \mathrm{L} \mathrm{SD})$ and lowest in the gill $(65.00 \pm 27.39 \mathrm{IU} / \mathrm{L}$ $\mathrm{SD})$ in the control group. There was no significant change in AST activity in the liver across the treatment range. AST activity however declined in the muscle with the lowest at 6ppm of paraquat. There was a significant increase in AST activity in the gills at $4 \mathrm{ppm}$ of paraquat, this later declined to almost control levels at higher concentrations. In the kidneys AST activity also significantly peaked at 4ppm of paraquat. This declined slightly and was maintained at higher treatment concentrations. AST activity peaked in the plasma at $4 \mathrm{ppm}$ of paraquat as well. This dropped slightly and picked up at $8 \mathrm{ppm}$. All these are illustrated in the Figure 1.

*Corresponding author: Wala Chimela, Department of Biological Sciences Faculty of Science, Nigeria Police Academy, Wudil Kano, Nigeria, Tel: 234084817941; E-mail: wala_c@yahoo.com

Received January 20, 2014; Accepted February 21, 2014; Published February 24, 2014

Citation: Chimela W, Mesua N, Abdulraheem BA (2014) Aspartate Transaminase (AST) Activity in Selected Tissues \& Organs of Clarias Gariepinus Exposed To Different Levels of Paraquat. J Environ Anal Toxicol 4: 214. doi: 10.4172/21610525.1000214

Copyright: (c) 2014 Chimela W, et al. This is an open-access article distributed under the terms of the Creative Commons Attribution License, which permits unrestricted use, distribution, and reproduction in any medium, provided the original author and source are credited. 


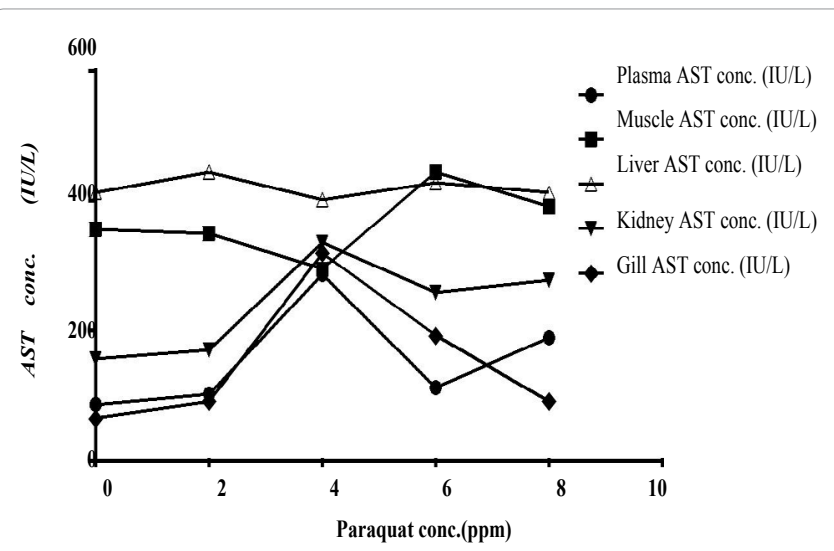

Figure 1: Relative Aspartate Transaminase (ALT) activity in organs of Clarias garienpus exposed to various levels of paraquat for 30 days.

\section{Discussion}

The exposure of Clarias gariepinus to paraquat lead to changes in the activity of AST in the organs investigated except the liver. Where changes were found, it could suggest that there is an inactive or ineffective transamination and oxidative deamination processes in these organs. This finding can also indicate a breakdown of the promotion of gluconeogenesis from amino acids as well as disruption in aminotransferase activities in the organs all of which could be as a result of tissue damage. Similar results have been reported by Gill et al. [2] in the liver, gill and kidney of Barbus Conchonius exposed to $12.6 \mathrm{mg} / \mathrm{l}$ of cadmium chloride for 48 hours with the gills mostly affected by cadmium poisoning. Cyprinus carpio exposed to $32.5 \mathrm{mg} / \mathrm{l}$ of diazinon for 90hours produced depressed activities in AST in the liver and muscle. Grass carp exposed to $2.0 \mathrm{mg} / \mathrm{l}$ of diquat experienced significant difference in levels of the enzyme activity. The increase in the activity may be due to disturbance in the Kreb's cycle. Decreased activity in Kreb's cycle causes a decrease in Krebs cycle intermediates $[3,4]$ which could cause cell death and subsequently tissue damage.
The increase in enzyme activity in the study indicates that there might be tissue damage, because fish enzymes (AST inclusive) are the most sensitive biomarkers employed in the diagnosis of hepatic damage since they are cytoplasmic in nature and are released into circulation (blood) after cellular damage [5,6]. Enzyme activity in the gills, plasma and kidneys peaked at $4 \mathrm{ppm}$ of paraquat and later declined slightly. This decline could have been as a result of enzyme saturation or enzyme inhibition.

\section{Conclusion}

Organ damage caused by paraquat exposure resulted in increased enzyme activities in the plasma gills and kidney but no change and a reduced activity in the liver and muscle respectively. It can consequently be inferred that AST activity can be used as a reliable biomarker for diseased condition in the plasma, gills and kidney but not the liver or muscle of Clarias gariepinus.

\section{References}

1. Horsfall MJ, Spiff Al (2007) Principles of Environmental Pollution (with, physical, chemical and biological emphasis) 2nd edn, Metroprints Ltd, Port Harcourt 317.

2. Gill TS1, Tewari H, Pande J (1991) In vivo and in vitro effects of cadmium on selected enzymes in different organs of the fish Barbus conchonius Ham. (rosy barb). Comp Biochem Physiol C 100: 501-505.

3. Chetty CS, Naidu RC, Reddy YS, Aruna P, Swami KS (1980) Tolerance limits and detoxication mechanisms in fish Tilapia mossambica subjected to ammonia toxicity. Indian Journal of Fisheries 27: 177-182.

4. Prasada Rao KS, Ramana Rao KV (1984) Tissue specific alteration of aminotransferases and total ATPases in the fish (Tilapia mossambica) under methyl parathion impact. Toxicol Lett 20: 53-57.

5. Mayne DP (2002) Clinical chemistry in diagnosis and treatment. 6th edn Annold, 338 Euston Road, London.

6. Pari L1, Amali DR (2005) Protective role of tetrahydrocurcumin (THC) an active principle of turmeric on chloroquine induced hepatotoxicity in rats. J Pharm Pharm Sci 8: 115-123. 